\title{
PROGRAM PEMULIHAN PELANCONGAN PASCA BENCANA GEMPA BUMI 2015 DI SEKITAR PINGGIRAN GUNUNG KINABALU, KUNDASANG: CABARAN DAN STRATEGI
}

\section{POST EARTHQUAKE DISASTER RECOVERY PROGRAM 2015 : CHALLANGES AND STRATEGIES}

\author{
Raihan Binti Anas, Rosazman Hussin \& Badariah Ab Rahman \\ Institut Kajian Orang Asal Borneo (BorIIs), \\ Fakulti Kemanusiaan, Seni dan Warisan \\ Universiti Malaysia Sabah, Malaysia \\ raianasums@gmail.com
}

\begin{abstract}
This study is about a post-earthquake disaster recovery program in Kundasang located on the outskirts of Mount Kinabalu, Ranau Sabah. Therefore, this study reviews the post-disaster tourism recovery program conducted by members of the local community to revive existing tourism products. The main approach of this study is the qualitative approach. Methods of collecting data such as in-depth interviews with seven informants involved. Besides, field observations have been applied to obtain more in-depth data for this study. The results show that the community in Kampung Mesilou Kundasang has been directly and actively involved in the post-disaster tourism recovery program. The findings show that there are issues and challenges faced by community members whose issues and challenges are different in the process of implementing and implementing the post-earthquake earthquake recovery program in Sabah Kundasang.
\end{abstract}

Key words: Tourism, Local Communities, Challenges, Post-disaster Recovery Program, Earthquakes

\section{ABSTRACT}

Kajian ini adalah tentang program pemulihan pelancongan pasca bencana gempa bumi di Kundasang yang terletak di pinggiran Gunung Kinabalu, 
Ranau Sabah.Gempa bumi yang berlaku pada 05 Jun 2015 di kawasan Gunung Kinabalu telah menyebabkan aktiviti pelancongan di sekitar Kundasang telah terjejas. Oleh itu, kajian ini meninjau program pemulihan pelancongan pasca bencana yang dilakukan oleh ahli komuniti setempat untuk memulihkan semula produk pelancongan yang sedia ada. Pendekatan utama kajian ini adalah pendekatan kualitatif. Kaedah kutipan data seperti temubual mendalam kepada tujuh orang informan yang melibatkan ahli komuniti yang berkepentingan. Selain itu, pemerhatian di lapangan telah diaplikasikan untuk mendapatkan data yang lebih mendalam bagi kajian ini. Hasil kajian mendapati bahawa komuniti di Kampung Mesilou Kundasang telah terlibat secara langsung dan aktif dalam program pemulihan pelancongan pasca bencana. Hasil kajian mendapati bahawa wujud isu serta cabaran yang dihadapi oleh ahli komuniti dimana isu dan cabaran yang dihadapi adalah berbeza dalam proses melaksanakan dan semasa melaksanakan program pemulihan pelancongan pasca bencana gempa bumi di Kundasang Sabah.

Kata Kunci: Pelancongan, Komuniti setempat, Cabaran, Program Pemulihan Pasca Bencana, Gempa bumi

\section{Pengenalan}

Khazanah alam semula jadi seperti sumber hutan, tanah tinggi, pulau dan pantai adalah salah satu tarikan pelancong di Malaysia. Menurut Amran (1997), destinasi berasaskan alam semula jadi memainkan peranan yang penting dalam mempromosikan sektor pelancongan di Malaysia. Perkembangan industri pelancongan yang berasaskan alam semula jadi selalunya mempunyai keistimewaan tersendiri yang mendorong para pelancong berkunjung ke destinasi berkenaan.

Sabah adalah sebuah negeri yang terkenal dengan tarikan pelancongan seperti pulau-pulau kecil, hutan simpan, dan juga keunikan serta keindahan Gunung Kinabalu yang mempunyai daya tarikan utama pelancongan di Sabah. Kundasang, satu nama yang tidak perlu diperkenalkan lagi dalam industri pelancongan di Malaysia. Kedinginan angin bayu yang mencecah $21^{\circ} \mathrm{C}$ adalah suatu tarikan pelancong untuk ke Kundasang dan menikmati keindahan serta kemegahan Gunung Kinabalu. 
Namun, bencana gempa bumi yang melanda bumi Sabah iaitu berukuran 5.9 skala ritcher yang terjadi di Ranau Sabah telah mengegarkan bumi Sabah. Ini adalah antara bencana gempa bumi yang terbesar dan paling kuat pernah berlaku di Malaysia dalam tempoh 39 tahun sejak 1976. Gegaran pertama yang berlaku adalah pada tahun 1966 dengan kekuatan 5.3 skala ritcher dan kemudiannya pada tahun 1991 iaitu dengan kekuatan 5.1 skala ritcher dan catatan gegaran berikutnya adalah pada Mac 2005. Secara tidak langsung kejadian gempa bumi yang terjadi menyebabkan sektor pelancongan di Sabah terutama di Kundasang telah terjejas.

\section{Metod Kajian}

Bagi menjalankan kajian ini, berikut adalah ringkasan metodologi kajian yang digunakan:

Jadual 1: Rumusan Metodologi Kajian

\begin{tabular}{|ll|}
\hline Kaedah Kajian & Kajian Kualitatif \\
\hline Kaedah Kajian & Kajian Kualitatif \\
\hline Reka bentuk Kajian & Kajian Kes \\
\hline Persampelan & Persampelan Bertujuan \\
\hline Bilangan Responden & 7 \\
\hline Teknik Pengumpulan Data & Temubual Mendalam \\
& Pemerhatian Turut Serta \\
\hline Instrumen Kajian & Panduan soalan \\
& Perakam Suara \\
& Nota lapangan \\
\hline Analisis Kajian & Analisis Tema \\
\hline
\end{tabular}

Kajian yang dijalankan ini adalah kajian kualitatif yang menggunakan kajian kes sebagai reka bentuk kajian. Ini kerana kajian kes adalah suatu strategi penyelidikan yang memfokus kepada suatu organisasi, institusi, acara, keputusan, dasar atau kumpulan. Ia adalah suatu kajian pemerhatian terhadap sesuatu persekitaran seperti senario penyertaan komuniti dalam program pemulihan pelancongan. Penerangan yang kompleks dan pemahaman yang mendalam diperlukan bagi mendalami masalah sebenar yang dihadapi oleh ahli komuniti yang terlibat dalam program pemulihan pelancongan pasca bencana. 
Oleh itu, ia hanya boleh diperoleh dengan berkunjung ke tempat kejadian dan bertemu sendiri dengan ahli komuniti yang terlibat untuk berkongsi cerita dan pengalaman serta melontarkan suara dan isi hati mereka tentang masalah yang dihadapi terutamanya selepas berlaku bencana gempa bumi dan memahami pelbagai usaha yang dilakukan unrtuk memulihkan semula program serta produk pelancongan yang ada. Dalam konteks ini, kajian kualitatif sangat sesuai diaplikasikan untuk memahami kajian ini.

\section{Latar Belakang Geografi Kampung Mesilou}

Ranau terletak di bahagian tengah negeri Sabah (Ramzah \& Buang, 2008) yang juga adalah kawasan yang paling besar menerima impak gegaran gempa bumi. Kundasang adalah suatu mukim yang terdapat di dearah Ranau dan menjadi tempat tumpuan pengunjung ke Sabah. Kampung yang terletak di pinggiran Gunung Kinabalu dijadikan sebagai lokasi kajian, Pekan kecil Kundasang yang terletak kira-kira 15 Kilometer dari pekan Ranau yang juga dikenali sebagai "Pekan Sayur" mempunyai suhu yang agak sejuk berbanding daerah-daerah yang lain di Sabah. Ramzah Dambul (2010) menyatakan bahawa dari segi skala geografi yang besar di negeri Sabah, wilayah Kundasang ini mempunyai beberapa ciri istimewa dari segi fungsi dan letakan.

Pada dasarnya sumber ekonomi utama penduduk Kundasang adalah daripada mengusaha aktiviti pertanian dan penanaman. Fujimoto dan Miyaura (2002) menyatakan bahawa kawasan Kundasang, yang terletak di lereng Gunung Kinabalu di Negeri Sabah, telah berkembang menjadi satu lagi tanah tinggi utama pengeluar sayur-sayuran di negara ini. Kundasang adalah sebuah bahagian di daerah Ranau di Sabah, Malaysia yang terletak di sepanjang tebing lembah Kundasang. Ia terletak kira-kira enam kilometer dari Taman Negara Kinabalu yang berjarak 12 kilometer dari pekan Ranau.

Kawasan kundasang ini mempunyai beberapa buah kampung utama yang sangat dikenali oleh orang ramai antaranya ialah Lembah Permai, Cinta Mata, Kauluan, Sinisian, Dumpiring dan Kinasaraban. Kundasang adalah 
bahagian yang paling dekat dengan Gunung Kinabalu dan mempunyai pemandangan panorama gunung. Etnik utama di Kundasang ialah etnik asli Dusun dan penduduk kecil orang Cina. Hampir kesemua kedai yang ada di Kundasang di kendalikan oleh komuniti tempatan.

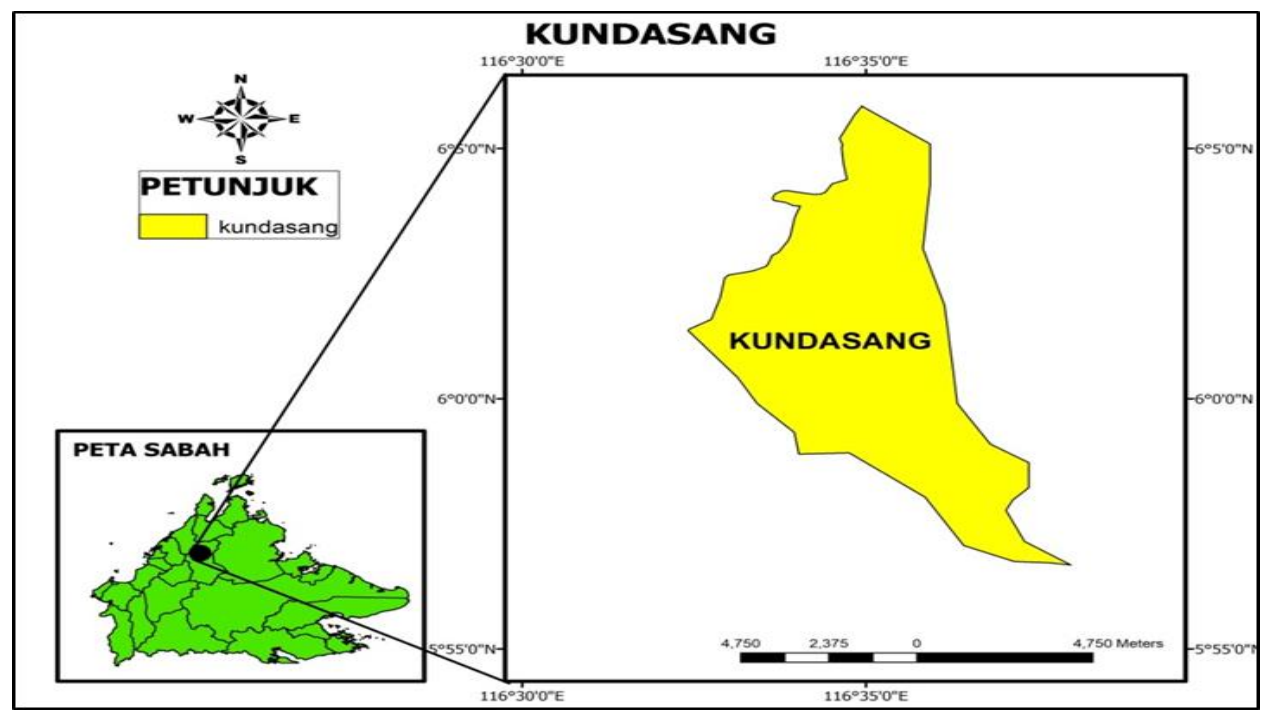

Peta Mukim Kundasang

Sumber : Kerja Lapangan 2017 


\section{Ciri Tarikan Pelancongan Di Kampung Mesilou Kundasang Sabah}

Secara umumnya tarikan pelancongan di Kampung Mesilou adalah berasaskan sumber semula jadi, budaya dan warisan. Sumber semula jadi di Kampung Mesilou terdiri daripada keindahan Gunung Kinabalu, kesejukan angin gunung yang adalah suatu kawasan tanah tinggi yang terdapat di Sabah, keunikan flora dan fauna. Sumber tarikan budaya pula termasuklah petempatan komuniti Dusun yang sememangnya menjadi identiti utama di negeri Sabah. Walaupun terdapat pelbagai sumber yang menjadi tarikan pelancong, tarikan sumber alam semula jadi dikatakan sebagai sumber utama pembangunan pelancongan di kawasan tersebut.

\section{Latar Belakang Program Pelancongan}

Secara amnya, Kundasang mempunyai bentuk muka bumi yang agak berbukit dan sesuai untuk dibangunkan sebagai kawasan pelancongan. Antara kawasan yang menjadi tumpuan pelancong semestinya adalah Gunung Kinabalu dan beberapa kawasan yang menarik seperti Desa Dairy Farm yang juga mendapat jolokan nama "New Zealand Sabah", Mesilou Nature Resort, Arnab Village, Mesilou Cats Village, dan beberapa kampung yang dijadikan homestay seperti Atamis Homestay yang terletak di Kampung Mesilou yang juga dikenali sebagai "The Highest and The Coldest Homestay in Malaysia". Justeru, tidak hairanlah jika banyak pembangunan homestay, hotel mahupun resort dibangunkan di sekitar pinggiran kampungkampung yang terdapat di Kundasang.

Namun begitu, kampung yang paling terjejas teruk kesan daripada gempa bumi adalah program dan produk pelancongan di Kampung Mesilou. Kampung Mesilou adalah suatu kampung yang terdapat di Kundasang. Kampung Mesilou ini terletak dibahagian paling atas jika dibandingkan dengan kampung-kampung yang ada di Kundasang. Kampung Mesilou terletak kira-kira 85 kilometer dari pusat bandaraya Kota Kinabalu. Kampung Mesilou, dinamakan selepas Mesilou River, adalah kawasan yang terletak kira-kira $2000 \mathrm{~m}$ di atas paras laut di East Ridge Gunung Kinabalu di Taman Negara Kinabalu, Sabah, Malaysia. Kampung Mesilou merupakan tapak Mesilou Nature Resort, yang dimiliki dan dikendalikan oleh Sutera Sanctuary Lodges. Selain itu Kampung Mesilou adalah salah satu daripada dua laluan utama sidang kemuncak Gunung Kinabalu yang bermula di Mesilau Nature Resort dan dikenali Trail Mesilou. The Mesilou Trail adalah berhampiran dengan laluan lama Summit Kinabalu Trail yang terletak di atas 
Layang-Layang (Dusun untuk Tempat Swallows), yang terletak kira-kira $2700 \mathrm{~m}$.

\section{Tahap Penglibatan Komunti Dalam Pelancongan Berasaskan Komuniti}

Dalam konteks ini, perkara yang paling penting ditekankan dalam pelancongan adalah penyertaan komuniti. Menurut Tosun (1999) pembangunan pelancongan memerlukan penglibatan komuniti secara langsung dalam membuat keputusan. Oleh itu penyertaan komuniti dapat dikenal pasti melalui dua perspeektif iaitu proses membuat keputusan dan faedah daripada pembangunan pelancongan (Tosun, 1999; Murphy, 1985).

Pelaksanaan pelancongan berasaskan komuniti bukan suatu perkara yang mudah kerana memerlukan usaha dan jangka masa yang panjang (Kathilia, 2015). Tambahan pula, pelancongan berasaskan komuniti adalah bersifat skala kecil dan kadar keuntungan yang rendah. Menurut Maureen (1997) beberapa penyelidik mengemukakan beberapa model perancangan pelancongan berasaskan komuniti seperti Gunn (2002) dan Murphy ( 1985). Berdasarkan daripada teori dan model yang telah diperkenalkan oleh pelbagai penyelidik dapat dirumuskan bahawa di peringkat awal pelaksanaan pelancongan berasaskan komuniti haruslah bermula dengan penyertaan komuniti (Kathlia, 2015).Oleh itu tiplogi penglibatan komuniti yang dikemukan oleh Pretty (1995) menerangkan setiap satu daripada tahap tersebut yang perlu ada dalam menjayakan sesebuah program.

Jadual 1.2 Tipologi Penglibatan Komuniti

\begin{tabular}{|l|l|}
\hline Bentuk penyertaan & \multicolumn{1}{|c|}{ Penjelasan } \\
\hline $\begin{array}{l}\text { Penglibatan } \\
\text { manipulatif }\end{array}$ & $\begin{array}{l}\text { Penglibatan komuniti dalam jenis ini adalah yang } \\
\text { bersifat lakonan. Individu yang mewakili komuniti } \\
\text { dimeja rundingan tidak dipilih secara rasmi dan tidak } \\
\text { berkuasa untuk membuat sebarang keputusan }\end{array}$ \\
\hline Penglibatan pasif & $\begin{array}{l}\text { Hubungan antara pengarah projek dan ahli komuniti } \\
\text { adalah sehala. Pengarah projek tidak mengambil kira } \\
\text { respon ahli komuniti. Ahli komuniti terlibat kerana } \\
\text { diberi soal jawab atau menjawab soal selidik yang } \\
\text { diberikan. Namun agen luar yang mendefinisikan }\end{array}$ \\
\hline
\end{tabular}




\begin{tabular}{|c|c|}
\hline & $\begin{array}{l}\text { masalah. Keadaan ini menyebabkan pembuatan } \\
\text { keputusan diiakukan oleh orang di luar komuniti }\end{array}$ \\
\hline $\begin{array}{l}\text { Penglibatan } \\
\text { Konsultasi }\end{array}$ & $\begin{array}{l}\text { Komuniti dinasihatkan terlibat dalam projek, namun } \\
\text { agensi luar masih mengawal semua proses } \\
\text { pembangunan }\end{array}$ \\
\hline $\begin{array}{l}\text { Penglibatan } \\
\text { Insentif }\end{array}$ & $\begin{array}{l}\text { Komuniti menyumbang tenaga buruh kerana tidak } \\
\text { mendapat wang tunai atau bahan lain misalnya petani } \\
\text { mungkin terlibat dengan kerja harian tetapi tidak } \\
\text { terlibat dalam membua keputusan. Tetapi masih } \\
\text { dianggap sebagai penglibatan, dan penglibatan } \\
\text { berakhir apabila insentif berakhir. }\end{array}$ \\
\hline Penglibatan Fungsi & $\begin{array}{l}\text { Di lihat oleh agensi luar untuk capai atau laksana } \\
\text { projek sepert mengurangkan kos pembangunan. } \\
\text { Komuniti terlibat tetapi tidak sepenuhnya. Keputusan } \\
\text { akhir telah ditentukan oleh agen pembangunan luar. }\end{array}$ \\
\hline $\begin{array}{l}\text { Penglibatan } \\
\text { Interaktif }\end{array}$ & $\begin{array}{l}\text { Komuniti terlibat dalam kerjasama dengan agen } \\
\text { pembangunan dan perancangan. Tindakan } \\
\text { pembangunan mengukuhkan institusi tempatan dan } \\
\text { penglibatan komuniti bukan sahaja untuk capai } \\
\text { matlamat projek tetapi juga melibatkan proses } \\
\text { pembelajaran dan pelbagai perspektif. Keputusan } \\
\text { pembangunan diperingkat tempatan dikuasai oleh } \\
\text { komuniti misalnya komuniti menentukan sumber } \\
\text { untuk digunakan dan dikekalkan. }\end{array}$ \\
\hline $\begin{array}{l}\text { Penglibatan } \\
\text { Kendiri }\end{array}$ & $\begin{array}{l}\text { Komuniti terlibat melalui inisiatif sendiri dengan } \\
\text { bebas. Mereka membina hubungan atau konteks } \\
\text { dengan institusi luar bagi memperoleh sumber dan } \\
\text { nasihat teknikal yang diperlukan. }\end{array}$ \\
\hline
\end{tabular}

Sumber: Pretty (1995)

Penglibatan tempatan adalah satu proses yang dinamik. Ini bermakna tahap penglibatan komunti tempatan pada permulaan pembangunan pelancongan tidak semestinya berkekalan selama-lamanya. Kesedaran ini adalah penting memandangkan perubahan kepada kapasiti komuniti tempatan akan menyebabkan perubahan kepada tahap penglibatan tempatan. 


\section{Fasa Program Pemulihan Pelancongan}

Oleh itu, fasa pertama yang dilakukan oleh komuniti adalah dengan mengadakan perjumpaan sesama ahli komuniti untuk membincangkan cara dan kaeadah untuk menarik pelancong untuk kembali dan datang semula ke Kampung Mesilou. Perbincangan yang dilakukan lebih berfokus untuk mengenalpasti keadaan serta kerosakan yang berlaku selepas bencana gempa bumi terjadi. Hasil pemeriksaan yang dilakukan oleh komuniti, komuniti mendapati bahawa banyak infrastruktur telah rosak akibat bencana gempa bumi. Selain itu juga, produk pelancongan yang ada di Kampung Mesilou turut musnah dengan teruk dan tidak boleh dibaiki. Komuniti telah mengadakan perjumpaan secara kerap dengan ahli komuniti untuk membincangkan tindakan yang perlu diambil.

Dalam perjumpaan yang diadakan pelbagai program dirancang dan dilaksanakan secara berperingkat. Penyertaan komuniti adalah aktif yang mana semua komuniti terlibat secara langsung dalam proses pemulihan yang dilaksanakan. Oleh itu dalam konteks ini dapat dilihat bahawa penglibatan komuniti adalah secara langsung yang mana komuniti telah memberi pendapat mereka dalam membentuk masa depan yang melibatkan penyertaan mereka secara langsung. Ini sejajar dengan pendapat Mckercher (1998) yang menegaskan bahawa kepentingan penglibatan komuniti adalah perlu dalam setiap perancangan dan pengurusan pelancongan.

Fasa kedua adalah proses pemulihan pelancongan di Kampung Mesilou. Proses pemulihan ini lebih berfokus kepada pembaikpulihan produk pelancongan seperti kemudahan infrastruktur dan juga sungai. Antara kerosakan yang diperbaiki dan dipulihkan adalah seperti pembaikan paip air yang pecah dan musnah, pemulihan sungai dan pengalihan batu, pemulihan jambatan kampung sebagai laluan utama ke ladang komuniti yang juga digunakan sebagai laluan pelancong untuk melawat ladang komuniti. Namun begitu usaha yang dilakukan tidak berjaya sepenuhnya memandangkan gegaran susulan kerap berlaku selepas gegaran pertama yang telah menyebabkan kerosakan semakin bertambah teruk.

Laluan sungai antara yang paling terjejas teruk kerana batu-batu yang telah jatuh dari atas Gunung Kinabalu telah menyebabkan laluan sungai menjadi kecil dan ikan-ikan yang ditagal telah tiada. Komuniti telah berusaha 
mengalihkan beberapa batu untuk memulihkan dan memastikan aliran air sungai mengalir seperti biasa. Berikutan masalah gegaran yang berterusan menyebabkan komuniti bekerja agak perlahan kerana bimbang akan keselamatan diri.

Fasa ketiga yang dijalankan adalah dengan mengadakan larian komuniti, iaitu Larian Mesilouthon. Larian Mesilouthon yang dilaksanakan adalah untuk menarik minat komuniti setempat dan orang luar datang berkunjung dan menginap di Mesilou. Larian ini dilaksanakan adalah kerana pemulihan fasa yang ke dua tidak berjaya. Aktiviti larian ini adala suatu penggerak utama dalam proses pemulihan pelancongan kerana penyertaan peserta daripada luar adalah sangat memberangsangkan iaitu lebih daripada 1 ribu penyertaan awam dan semasa aktiviti larian ini dilaksanakan, homestayhomestay serta tempat penginapan di sekitar Kampung Mesilou dan Kundasang ditempah oleh pelancong yang terlibat dengan larian ini.

Hal ini secara tidak langsung menjadikan pelancongan di Mesilou secara perlahan-lahan mula meningkat dari aspek kedatangan pelancong dan penginapan pelancong di homestay. Namun begitu, komuniti sedar bahawa larian ini hanya boleh dilakukan pada masa tertentu kerana aktiviti seperti ini memerlukan komitmen dan kerjasama daripada semua komuniti. Oleh itu komuniti bersetuju untuk menjadikan larian ini sebagai acara tahunan di Kampung Mesilou.

Komuniti Mesilou juga turut memperkenalkan produk pelancongan yang baru kepada para pengunjung. Produk pelancongan ini dikenali sebagai "Hiking Bukit yang diberi nama trail Bukit Maragang. Ini adalah fasa yang ke empat dalam program pemulihan pelancongan. Bukit Meragang ini diwujudkan kerana komuniti sedar bahawa perlunya produk lain yang boleh dikomersialkan dan kepada pelancong tanpa mengira masa. Hal ini demikian kerana Bukit Meragang ini boleh didaki setiap masa mengikut permintaan pelancong dan sekaligus mendatangkan keuntungan kepada komuniti di Kampung Mesilou. Oleh itu dengan adanya produk pelancongan ini, komuniti menerima manfaat kerana wujudnya peluang pekerjaan sekaligus memberi pendapatan sampingan kepada mereka. Secara tidak langsung ini telah menyumbang kepada peningkatan dan kepelbagaian sumber pendapatan mereka.

Pemulihan pelancongan amat bergantung kepada penyertaan komuniti. Dengan adanya penyertaan komuniti, program pemulihan dapat dilakukan 
dan berjaya mencapai matlamat. Namun syarat utama kepada kejayaan pemulihan pelancongan ini sememangnya terletak sepenuhnya kepada komuniti di kawasan tersebut. Oleh itu dapat disimpulkan bahawa walaupun komuniti menghadapi kesukaran dalam proses pemulihan produk pelancongan tetapi dengan adanya penyertaan dan kesepaduan yang kuat daripada semua komuniti menyebabkan program pemulihan ini berjaya dan penyertaan komuniti adalah berada di tahap ke enam dalam tipologi pretty iaitu tahap interaktif yang mana menurut Pretty (1995) penyertaan komuniti adalah dilihat sebagai satu hak. Komuniti terlibat dalam mengekalkan struktur dan praktis projek pembangunan kerana mereka mengambil bahagian dalam membuat keputusan dan mempunyai hak dalam menentukan kegunaan sumber.

\section{Cabaran Pemulihan Program Pelancongan Di Kampung Mesilou}

Hasil kajian mendapati terdapat empat cabaran utama yang diketengahkan oleh responden kajian iaitu kedatangan pelancong yang merosot selepas bencana gempa bumi, produk pelancongan yang musnah,tidak mempunyai pengetahuan dalam memulihkan pelancongan, dan tidak mendapat bantuan khas daripada pihak kerajaan untuk tujuan pemulihan pelancongan Setiap cabaran dibincangkan seperti berikut :

\section{Kedatangan Pelancong Yang Merosot}

Dalam konteks kedatangan pelancong setelah bencana gempa bumi, produk pelancongan tidak mendatangkan hasil malah mendatangkan kerugian kepada pelancongan dan komuniti sekitar Mesilou kerana banyak aktiviti yang telah dirancang terpaksa ditangguhkan dan ada yang terpaksa dibatalkan. Ini adalah disebabkan kebimbangan pelancong untuk datang kerana mendapat berita mengenai gempa bumi yang terjadi sekaligus menyebabkan pelancong untuk membatalkan perjalanan ke Kundasang secara amnya. Hal ini sekaligus menyebabkan komuniti perlu bertindak untuk memulihkan produk pelancongan yang ada.

\section{Produk Pelancongan Yang Musnah Akibat Bencana Gempa Bumi}

Selain itu juga, produk pelancongan yang sedia ada sebelum berlaku bencana gempa bumi telah musnah dan ini menjadi satu cabaran dan masalah kepada komuniti kerana produk pelancongan yang ditawarkan kepada pelancong adalah tarikan utama di Kampung Mesilou. Dalam konteks ini, pemulihan telah dilakukan namun menemui jalan buntu kerana keadaan sungai tidak 
dapat digunakan sebagai tarikan lagi di Mesilou disebabkan oleh tidak ada ikan-ikan yang boleh dipamerkan dan dinikmati oleh para pelancong disebabkan laluan sungai menjadi semakin kecil akibat runtuhan batu yang jatuh di sungai Mesilou.

Dalam konteks cabaran lain pula ialah laluan untuk melawat ke ladang komuniti juga menemui jalan buntu. Hal ini demikian kerana pelancong yang datang untuk melawat perlu melalui jalan yang jauh berbanding dulu. Masalah yang dihadapi adalah laluan yang baru itu adalah agak jauh dan tidak boleh digunakan oleh pelancong memandangkan jalan tersebut tidak berturap dan agak teruk. Oleh itu komuniti terpaksa menutup laluan tersebut dan tidak menawarkan lagi produk pelancongan itu. Hal ini jelas menyebabkan produk pelancongan komuniti semakin berkurang dan itu memberikan tekanan kepada komuniti untuk menghasilkan produk pelancongan baru bagi menggantikan produk pelancongan yang sedia ada.

3. Tidak Mempunyai Pengetahuan Dalam Memulihkan Pelancongan Antara isu yang timbul dan menjadi cabaran kepada komuniti adalah, komuniti tidak mempunyai pengetahuan mengenai program pemulihan yang perlu dilakukan. Dalam erti kata yang lain, komuniti tidak mendapat bimbingan daripada agensi bagaimana untuk memulihkan pelancongan kerana agensi cuma berfokus dalam membantu komuniti kampung dan bukannya pelancongan yang ada di Kampung Mesilou. Secara tidak langsung ini menjadi cabaran kepada komuniti untuk mempelajari ilmu berkaitan pemulihan pelancongan.

4. Tidak Mendapat Bantuan Khas daripada Pihak Kerajaan Untuk Tujuan Pemulihan Pelancongan

Dalam konteks sumber kewangan, pihak berwajib tidak mempunyai peruntukan untuk diberikan kepada komuniti Kampung Mesilou untuk tujuan pemulihan. Cabaran utama yang dihadapi oleh komuniti Mesilou adalah masalah sumber kewangan untuk memulakan aktiviti pemulihan. Oleh itu pemulihan pelancongan adalah atas inisiatif komuniti itu sendiri. Komuniti tidak mendapat bantuan untuk program pemulihan pelancongan tetapi komuniti mendapat bantuan asas seperti keperluan asas untuk kegunaan harian sahaja. 


\section{Cadangan Strategi Program Pemulihan Pelancongan}

Dalam kes pemulihan pelancongan, agensi kerajaan hanya memfokus kepada pemulihan restorasi gunung kinabalu. Hal ini kerana ia dikatakan sebagai elemen utama yang menarik kehadiran pelancong ke sabah amnya. Sememangnya perkara ini tidak dapat dinafikan namun begitu, komuniti juga perlu diberi bantuan dari aspek ilmu pengetahuan tentang pemulihan yang perlu dilakukan. Penyelidik mendapati peranan pihak kerajaan hanya memberi fokus kepada elemen utama iaitu pemulihan restorasi gunung kinabalu dan sokongan hanya diberikan apabila program pemulihan di kampung mesilou sudah pulih hasil inisiatif komuniti sendiri.

Sepertimana yang dibincangkan dalam kegiatan pemulihan pelancongan, peranan pihak kerajaan agensi pelancongan swasta dan badan bukan kerajaan perlu memberi bantuan khidmat nasihat berkaitan program pemulihan.Dalam aspek psikologi juga komuniti menyatakan bahawa hanya badan bukan kerajaan sahaja yang datang memberi bantuan khidmat psikologi selepas berlaku bencana. Oleh itu setiap pihak perlu memainkan peranan yang penting dalam memastikan pemulihan pelancongan adalah sekata walaupun pelancongan di kampung mesilou ini adalah elemen luar yang tidak mempengaruhi kehadiran pelancong ke Sabah.

Selain itu pihak kerajaan perlu bergerak secara agresif untuk memperkuatkan dan mengembangkan jalinan yang baik dengan komuniti. Jalinan hubungan ini perlu untuk menjayakan program yang dijalankan oleh komuniti. Hal ini sekaligus dapat memperkasakan komuniti itu sendiri. Pemantauan yang berterusan dan perbincangan bersama pelbagai agensi kerajaan mewujudkan kesamaan pendapat dan sekaligus mendapatkan konsensus bukan sahaja di peringkat agensi tetapi juga di peringkat komuniti.

Tujuannya adalah untuk mengelakkan konflik dan semua pihak akan mendapat manfaat. Oleh itu, semua pihak perlu menerima timbal balik untuk mewujudkan kepentingan bersama. Sehubungan itu, sikap saling percaya, terbuka dan jujur adalah elemen yang perlu ada antara pihak kerajaan dan juga komuniti (Viessman, 1993).

\section{Kesimpulan}


Kesimpulan, terdapat empat cabaran yang dihadapi oleh komuniti selepas bencana gempa bumi iaitu kedatangan pelancong yang merosot; produk pelancongan yang musnah akibat bencana gempa bumi; tidak mempunyai pengetahuan dalam memulihkan pelancongan; masalah; serta cabaran terakhir adalah tidak mendapat bantuan khas daripada pihak kerajaan berbeza pula cabaran yang dihadapi oleh pihak berkepentigan iaitu tidak mempunyai peruntukan untuk disalurkan kepada kampung kerana fiokus utama dalah untuk merestorasi Gunung Kinabalu. Kesemua cabaran yang dibincangkan tersebut diakui oleh responden sebagai antara punca kepada masalah kurangnya daya tahan atau resiliensi responden untuk bangkit meneruskan kehidupan selepas bencana gempa bumi.

Komuniti yang berdaya tahan atau resiliensi adalah komuniti yang mempunyai keupayaan untuk bangkit dan pulih semula daripada situasi kritikal seperti bencana. Mereka dikatakan berkemampuan untuk kembali semula berfungsi dalam masyarakat dengan menggunakan sumber sedia ada yang dimiliki. Komuniti yang mempunyai daya tahan atau resiliensi yang tinggi dikatakan mampu menjaga integriti fizikal alam sekitar dan kehidupan dan memastikan ekonomi, pentadbiran dan institusi sosial dapat berfungsi secara berterusan. Dalam sesebuah komuniti atau sistem sosial, pencapaian kefungsian sosial dilihat berdasarkan tanggungjawab dan tindakan sistem terhadap keperluan ahli dan hubungan timbal balik yang berlaku. Konsep ini menjelaskan tentang elemen interaksi yang wujud antara individu dan sistem persekitarannya. Interaksi akan membantu meningkatkan kefungsian sosial tetapi pada masa yang sama ia mungkin menimbulkan masalah kepada ketidakfungsian sosial. Setiap individu, kumpulan, atau komuniti secara semula jadi akan membentuk interaksi dengan individu, kumpulan atau komuniti yang lain.

Bantuan dan sokongan yang diberikan ini juga perlu seiring dengan pelaksanaan model pembangunan komuniti resilien di mana intervensi perlu melibatkan tiga peringkat iaitu peringkat individu di mana individu perlu mengetahui bahawa apa juga perkara kecil yang dilakukan mampu mengubah diri, keluarga dan komuniti secara positif. Individu juga digalakkan untuk membina kemahiran menyelesaikan masalah, mengukuhkan kepercayaan diri serta sentiasa bersedia dan berkebolehan untuk berhadapan dengan situasi kritikal. Peringkat kedua adalah komuniti di mana mereka digalakkan untuk terlibat secara aktif dalam aktiviti komuniti di samping membangunkan keupayaan komuniti untuk menyelesaikan masalah secara kolektif dan menyeluruh. Manakala peringkat ketiga pula 
adalah institusi di mana komuniti perlu disokong oleh agensi yang menggalakkan pemerkasaan dan kepimpinan dalam komuniti. Ia akan mendorong kepada wujudnya kepercayaan dan rasa hormat di antara ahli komuniti dan seterusnya membantu ahli komuniti dalam mencapai kesejahteraan hidup selepas bencana gempa bumi.

PENGHARGAAN

GERAN SBK 0333-2017: PENGLIBATAN KOMUNITI DAN STAKEHOLDER DALAM PROGRAM PEMULHAN SEKTOR PELANCONGAN PASCA BENCANA DI SABAH

\section{Rujukan}

Amran Hamzah. (1997). The Suistanability of Small-scale Tourism in Malaysia. Unpublished phD. Thesis. Norwich: University of East Anglia

Dambul, R., \& Buang. A. 2008. Pelancongan di Kundasang, Sabah: Journal Kekuatan dan kelemahan analisis positivisme. GeografiaMalaysian Jouof Society and Space 4, 20-31. Retrieved September 2 0, 2016. Available from: http//www.geografia.ukm.my.

Fujimoto, A., \& Miyaura, R. (2002). Farm management study of highland vegetable cultivation in Sabah, Malaysia: Farm questionnaire survey in Kundasang area. Journal of Agricultural Science-Tokyo Nogyo Daigaku (Japan).

Gunn (2002). Tourism Planning: Basic, Concept, Cases. New York Routledge.

Kathlia Sari Martokasumo (2015). Divergent Expectations: Case Studies of Community Based Tourism on the island of the Gods, Bali. Unpublished Thesis. Massey University, Palmerston North, New Zealand. 
Journal of Borneo Social Transformation Studies (JOBSTS), Vol. 5. No. 1, 2019

ISSN 2462-2095

Universiti Malaysia Sabah

Maureen Cubberley, (1997). "Community-based economic development and the library - a concept paper", Library Management, Vol. 18 Iss: 7, pp. $323-327$.

McKercher, B (1998). The Business of Nature Based Tourism. Victoria: Hospitality Press

Murphy, P.E. (1985) Tourism: A Community Approach. New York and London: Methuen.

Pretty J N. (1995): Participatory Learning for Sustainable Agriculture. World Development: forthcoming (August 1995) Vol. 23, No. 8.

Tosun, C (1998). Roots of unsustainable tourism developmentat the local level: The case of Urgup in Turkey. Tourism Management, 19 (6), 595-610

Viessman Jr, W. (1993). The water management challenge. Journal of Contemporary Water Research and Education, 90(1), 3. 